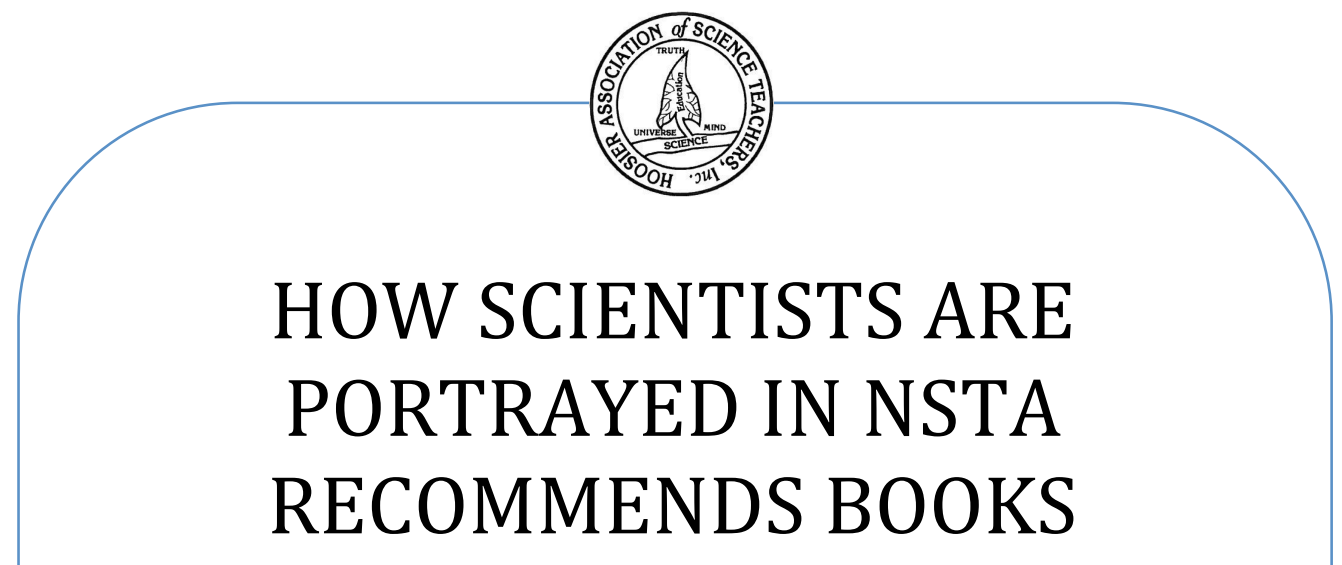

\author{
Kevin D. Finson \\ Bradley University • Peoria, Illinois \\ Donna Farland-Smith \\ The Ohio State University • Mansfield, Ohio \\ Cecile Arquette \\ Bradley University • Peoria, Illinois
}

If you use trade books or picture books in your science teaching, how do you choose which books to use with your students? How important is that decision? Do you rely on someone else to evaluate the books so you are assured of their appropriateness and quality? Such a practice is very common in today's educational circles. But is it the wisest course of action to take? We wondered about this, and designed a study to investigate the illustrations, images, or photographs of scientists portrayed in picture books promoted for use in elementary and middle school classrooms. Our focus was not on the stories being told in the books, but was on how the scientists were being portrayed specifically what the scientists looked like and what they were doing. The National Science Teachers Association has promoted itself as an organization that provides guidance to teachers to help them select the best resources for use in science instruction. Because of that, we decided to examine the trade books NSTA includes in their NSTA Recommends book lists. By their inclusion in these lists, books are implicitly viewed as being well vetted and of high quality with regard to their use in classrooms. 
It is no secret many elementary teachers are more comfortable with language arts than science (Kazempour, 2014). Given a choice, far too many will give science minimal time in their classroom instruction because of this. One way that science teaching can be made less intimidating is by utilizing literature as a bridge to the world of science. Specifically, the use of trade books and picture books can help teachers integrate literacy into science instructional time. Appropriate and well-done illustrations help children develop a language of science (beyond simple vocabulary), extending to the language of inquiry: observation, logically-derived hypothesizing, question-posing and examination of evidence (Pappas, 2006). Gains in these understandings of the language of science can be helpful to children as they develop their perceptions of what scientists do and how they conduct science investigations. This can help maximize students' understanding of specific content-related concepts.

There are, of course, numerous science concepts that can be the focus of science trade books. The one we choose to focus upon for our study was the concept of what scientists look like, who they are, and what they do. This is called "perceptions of scientists". It is not easy to determine exactly where students derive their perceptions of scientists. Farland-Smith, Finson, Boone, and Yale (2014) investigated this issue with 206 elementary students and identified a variety of potential sources of influence that could impact their perceptions of scientists. Those sources included media such as movies, television, and internet; books (including picture books, comic books, etc.); parents (e.g. imparting of values, informal activities, etc.); and schools (e.g. activities that occur there). Although each of these sources had impact, media sources were found to have the largest impact on students' perceptions of scientists.

Appropriately addressing perceptions of scientists is important for several reasons. First, it can impact students' understanding about where scientists work and what they do. In her 2006 study of third graders' perceptions of scientists, Farland found that weekly reading of non-fiction historical-based trade books depicting the work of scientists positively impacted students' perceptions of scientists. Second, the perceptions students have about scientists have direct linkages to student attitudes toward science and scientists (Finson, 2003; Fung, 2002), and positive attitudes are known to have significant influences on student success in science learning. A third reason is that an appropriate perception of scientists contributes to formation of science identity in children. Science identity includes one's perception that he/she can be a 


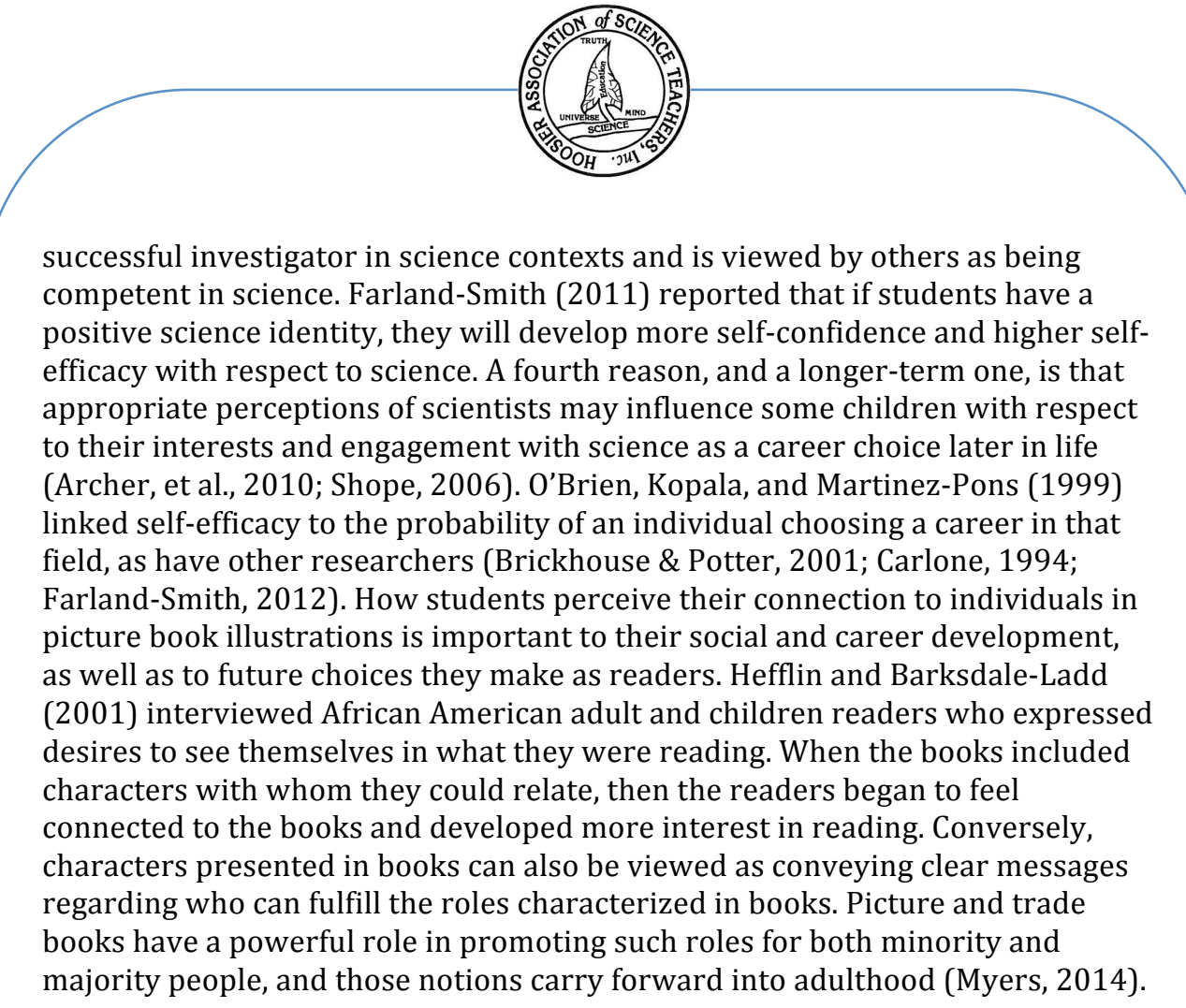

Science educators have consistently emphasized the need to help students see that science is a human endeavor. Science as a human endeavor was a significant component of the AAAS (1993) Benchmarks for Scientific Literacy (Project 2061) as well as the National Science Education Standards (NRC, 1996). In these documents, science as a human endeavor was described as people being engaged for a long time in science and technology, who contributed through history to the knowledge base, and included both men and women and various ethnicities. This has been continued in the Next Generation Science Standards (NGSS Lead States, 2013) through emphasis on explaining the importance of $\mathrm{K}-12$ students coming to know how scientists have investigated and answered fundamental questions in addressing major challenges facing society.

From the foregoing, it is reasonable to conclude that students who hold perceptions of how individuals in adult roles look and act. Science as a human endeavor in the $21^{\text {st }}$ century includes individuals from all races, ethnicities, and genders. If students only experience depictions of scientists in persistent forms 


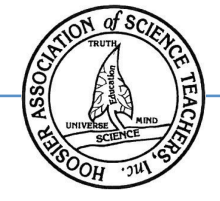

they may be unlikely to see or value science as an endeavor for themselves or anyone else now or in the future. One way to address these issues is through the use of science trade books and picture books in instruction (Farland, 2006a; Farland 2006b; Farland-Smith et al, 2012; Segun, 1988; Tapscott, 2009). But this is not without its potential pitfalls. For example, there is concern some books containing illustrations of scientists can actually create or foster perceptions about scientists that are not consistent with how scientists engage with their practice. Teachers need to have clear conceptions about scientists in order to identify misperceptions at their onset and then make use of tools and strategies to guide students in developing more desirable perceptions. The sheer number of tools and strategies available can be overwhelming, so teachers naturally look for some help in selecting the best ones. Within the context of integrating literature with science, helpful tools would include bibliographies or lists of trade books compiled by reputable agencies. Implied in this is the understanding that the agencies have properly vetted the trade books, and teachers can select books from those lists with little worry about conveying misperceptions about scientists.
\end{abstract}

\title{
Subjects of the Study
}

The subjects in this study were the books in the National Science Teachers Association's NSTA Recommends book lists for 2014, 2015, and 2016. We targeted children's picture books because they not only tell a story, but they give the reader an experience that is visual in nature. They are books that "display respect for children's understandings, abilities and appreciations" (ALSC, 2016). In contrast, children's chapter books rely on the written text to convey a story or information. Durkin (1974) defined trade books as those written for use in libraries or bookstores rather than being utilized as textbooks. The specific group of books we targeted from the NSTA Recommends lists were picture trade books that contained illustrations of scientists. For each of the books included in the study, we did not differentiate examination of illustrations made by authors as compared to those made by editors or production staff because our focus was on the final products (the books) that were available for children to obtain and read. Children are not concerned with who generated the illustrations in a book, but do respond to the contents of the illustrations. Hence, our focus was on the content of the illustrations. The illustrations in the books could be in a variety of formats, such as photographs, drawings, paintings, etc., but did represent some kind of image of a person.

Since the content of the books selected were about scientists, the illustrations of 


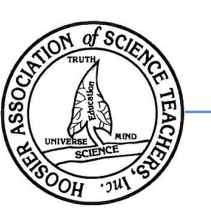

people within those books were those of scientists, even if the person illustrated was not shown actively doing science. For example, a person in an illustration may be shown sitting under a tree reading a book.

The specific number of books on the NSTA Recommends list varied across the three targeted years. In 2014, the total number of books was 55, in 2015 it was 49, and in 2016 it was 44 (see Table 1). Across those three years of books, the actual number of images of scientists also varied (see Table 2), ranging from a low of $4.18 \%$ in the 2016 books to a high of $18.34 \%$ in 2015 . Perhaps because we only examined books from three years, we found no particular trend in the number of images of scientists included in books. Some of the books showed scientists that could clearly be categorized as working in earth, life, or physical science. A total of 57 of the books could be classified as having orientation toward one of these three disciplines. The majority of images that could be classified in this way were of life and biological sciences (nearly three times the other disciplines), followed next by earth and then by physical science (see Table 3).

Table 1

Number of Books on NSTA Recommends List

\begin{tabular}{ccccccccc}
\hline & $\mathbf{2 0 1 4}$ & \multicolumn{9}{c}{$\mathbf{2 0 1 5}$} & \multicolumn{3}{c}{$\mathbf{2 0 1 6}$} \\
\hline $\begin{array}{c}\text { \# on } \\
\text { NSTA } \\
\text { List }\end{array}$ & $\begin{array}{c}\# \\
\text { Assessed }\end{array}$ & $\begin{array}{c}\text { \% } \\
\text { Assessed }\end{array}$ & $\begin{array}{c}\text { NSTA } \\
\text { NST } \\
\text { List }\end{array}$ & $\begin{array}{c}\# \\
\text { Assessed }\end{array}$ & $\begin{array}{c}\text { \% } \\
\text { Assessed }\end{array}$ & $\begin{array}{c}\text { NSTA } \\
\text { List }\end{array}$ & $\begin{array}{c}\# \\
\text { Assessed }\end{array}$ & $\begin{array}{c}\text { \% } \\
\text { Assessed }\end{array}$ \\
\hline 55 & 16 & 29.09 & 49 & 22 & 44.89 & 44 & 18 & 40.90 \\
\hline
\end{tabular}

Table 2

Number of Images in NSTA Recommends Books

\begin{tabular}{|c|c|c|c|c|c|c|c|c|}
\hline \multicolumn{3}{|c|}{2014} & \multicolumn{3}{|c|}{2015} & \multicolumn{3}{|c|}{2016} \\
\hline $\begin{array}{c}\# \text { of } \\
\text { Images }\end{array}$ & $\begin{array}{c}\# \text { of } \\
\text { Scientist } \\
\text { Images }\end{array}$ & $\begin{array}{c}\% \text { of } \\
\text { Images } \\
\text { That Are } \\
\text { Scientists }\end{array}$ & $\begin{array}{c}\text { \# of } \\
\text { Images }\end{array}$ & $\begin{array}{c}\text { \# of } \\
\text { Scientist } \\
\text { Images }\end{array}$ & $\begin{array}{c}\% \text { of } \\
\text { Images } \\
\text { That Are } \\
\text { Scientists }\end{array}$ & $\begin{array}{c}\# \text { of } \\
\text { Images }\end{array}$ & $\begin{array}{c}\# \text { of } \\
\text { Images of } \\
\text { Scientists }\end{array}$ & $\begin{array}{c}\text { \% of } \\
\text { Images } \\
\text { That Are } \\
\text { Scientists }\end{array}$ \\
\hline 6591 & 677 & 10.27 & 4361 & 800 & 18.34 & 4764 & 199 & 4.18 \\
\hline
\end{tabular}


Table 3

Scientists' Disciplines in Book Images

\begin{tabular}{ccccc}
\hline Year & \multicolumn{5}{c}{ Discipline } \\
\hline & Earth & Biology & Life & Physical \\
\hline $\mathbf{2 0 1 4}$ & 2 & 1 & 7 & 3 \\
\hline $\mathbf{2 0 1 5}$ & 6 & 4 & 11 & 3 \\
\hline $\mathbf{2 0 1 6}$ & 4 & 2 & 11 & 3 \\
\hline Total & 12 & 7 & 29 & 9 \\
\hline
\end{tabular}

\section{Instrumentation}

We assessed the images in the books using the Draw-A-Scientist-Test Checklist (DAST-C). The DAST-C was constructed using elements identified from a number of past studies on perceptions of scientists going as far back as the 1950s beginning with the classic Mead and Metraux study in 1957 in which they asked 35,000 high school students to write essays about what they thought scientists looked like. From these essays, the researchers were able to identify several consistent themes: a scientist was someone who was a middle-aged or elderly Caucasian male wearing a white lab coat and eyeglasses. He tended to work in dangerous laboratory settings. In 1983, Chambers followed on that study, but had students draw what they thought a scientist looked like rather than writing essays. From those drawings, he identified seven specific attributes that persisted across the students' drawings: men wearing lab coats and eyeglasses, having facial hair (like beards or mustaches), surrounded by symbols of research (e.g. scientific instruments), symbols of knowledge (e.g. books, periodic tables, filing cabinets), technology (e.g. rockets, computers), and relevant captions (e.g. "eureka!" or formulae). These attributes have become recognized as the elements comprising the "stereotypical" scientist.

In1995 study, Finson, Beaver and Cramond added to Chambers' work by developing a checklist-type instrument that could help quantify the attributes arising in drawings done by children about scientists. They called their instrument the Draw-A-Scientist-Test Checklist (or DAST-C). The DAST-C included within its checklist the elements or attributes identified by Chambers as well as some additional attributes that had emerged from literature on students' perceptions, including some later work done by Chambers. The elements from Chambers' work were included in the top half of the DAST-C, and the additional elements were included in the bottom half. Those additional 


\begin{abstract}
checklist items included such things as the ethnicity, gender, and age of the scientist, as well as the scientist's environment (doing work indoors, for example, or in areas of secrecy and/or danger). They also included mythic stereotypes (e.g. wild-haired and buzzing-eyed mad scientist-typologies or Frankenstein characteristics) and the presence of ideas represented by flashing light bulbs. In a way, the lower portion of the DAST-C can help illuminate the human endeavor aspect of what the scientist is doing since it helps one derive information about the environment in which the scientist is working and something about what the scientist is doing. When using the DAST-C, the presence of any of the elements is scored with a " 1 ", even if there are multiple appearances of that same element in the image, and the total is then added to derive a score for the drawing. Scores can be determined for the upper portion of the DAST-C (the classic portion), for the lower portion, and for the overall total. The higher the total DAST-C values, the more stereotypical the image is. One should note, however, a high score could occur when a drawing shows a chemist doing work while wearing safety goggles and a lab apron. In this case, this practice is stereotypical but consistent with how a trained scientist likely works. A copy of the DAST-C is included in Appendix A.
\end{abstract}

\title{
Methodology
}

The initial pool of picture books included for consideration in the study were those recommended by the National Science Teachers Association in its NSTA Recommends book lists for the years 2014, 2015, and 2016. A total of 148 books were identified for examination. We did not assess all books on the NSTA Recommends lists because some were for high school (our focus was on elementary and middle school), and the focus of this study was on books for primary and middle school levels. We obtained all 148 books through libraries in the Midwest. Only those books that contained images of scientists were selected for further assessment. This left us with 56 books (or $37.83 \%$ of the original 148 books) to assess. From that subset of books, we had a total of 15,778 images available for assessment. Since we were interested only in images of scientists, we pared down that set of images to just those actually showing scientists, and ended up with 1,676 images (just $10.66 \%$ of the original number of images in our pool). To be counted as a "scientist illustration," the illustration had to either be showing a person traditionally perceived as a scientist or a person doing science of some sort. 


\begin{abstract}
Considering the large volume of pictures now available for analysis, we were feeling a little overwhelmed and decided we needed to implement some sensible protocol allowing for easier management of picture assessment. We decided that for books having five or fewer scientist pictures, all pictures were to be analyzed. For any book having more than five scientist pictures, we would randomly select five images from the entire book based upon the assumption that those five would not vary significantly in their characteristics from the other pictures in the book. For several books with more than five scientist depicted we reviewed each illustration in the book to determine if our sampling method was representational and we determined our assumption was valid. An example of that validation is the book Primates by Ottaviani and Wicks. In that book, there were 495 pictures of scientists. However, the entire book was about the work of Jane Goodall, Dian Fossey, and Biruté Galdikas, and the pictures essentially repeated the same set of characteristics throughout the book. We then used the DAST-C on each of the selected images and derived scores for each of them. The scores of all the pictures in a single book were then used to calculate a mean DAST-C value for the book. This procedure also enabled us to determine a DAST-C mean for all books within a given year of the NSTA Recommends lists.
\end{abstract}

\title{
Analysis and Results
}

The data from our analyses are shown in Table 4. We conducted an analysis of variance (ANOVA) to the data to see if there were any significant differences in the images across the three years of books. We did not find any real differences, indicating that the kinds of images included in the books selected by NSTA for its NSTA Recommends list remained relatively constant across the years. That would likely be welcome news to the producers of the lists. However, there are three particular elements in the DAST-C results (all from the lower portion of the instrument) that warrant further thought. Those three focus on gender, race/ethnicity, and age.

\section{Conclusions/Discussion}

\section{Stereotypical Portrayals of Scientists}

The presence and influence of stereotypical images of scientists on learners is very prevalent in the research literature (Finson, 2002). That body of research has shown that the stereotypical nature of the images has been very persistent and resistant to change. Our analysis of the images of scientists in the NSTA 
Table 4

Presence of DAST-C Elements in NSTA Recommends Books

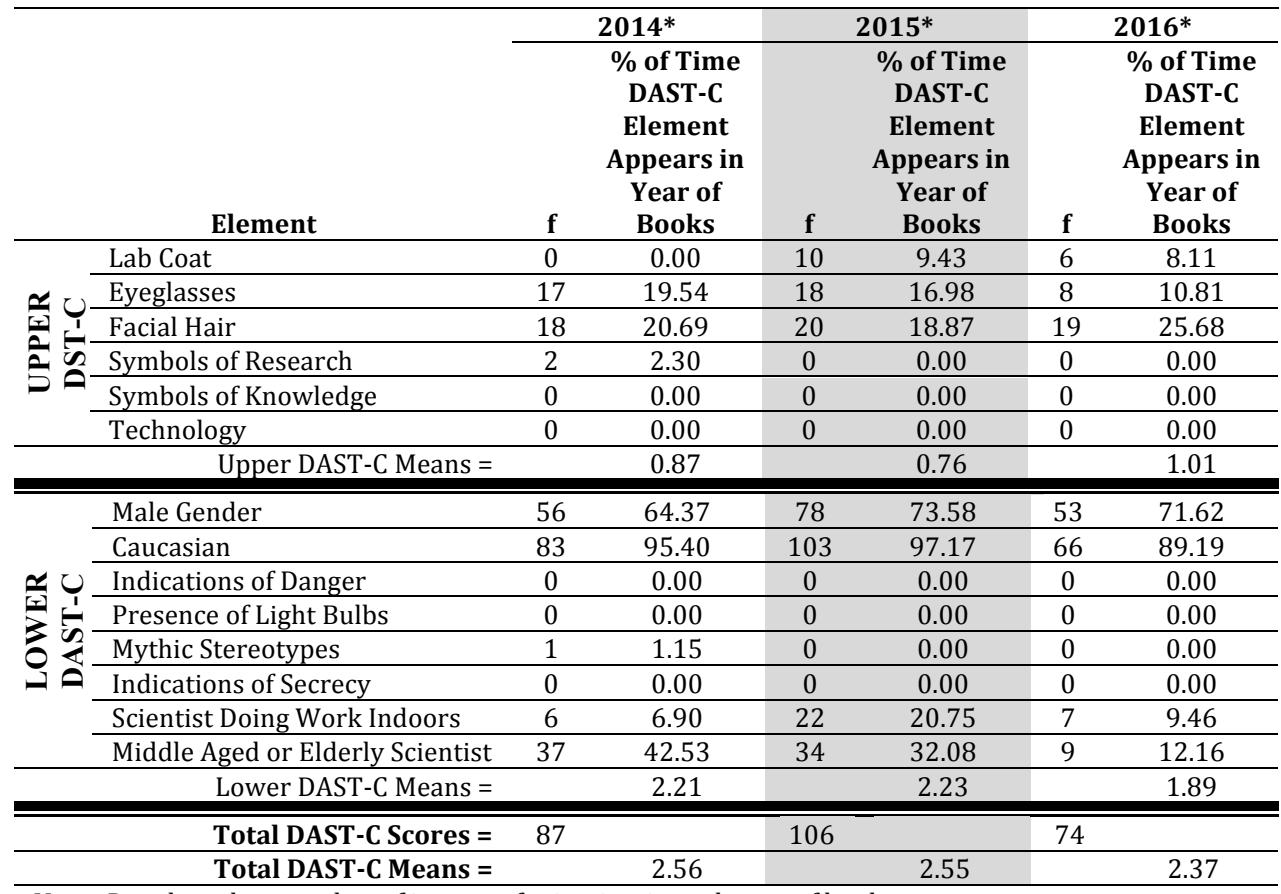

Note: Data based on number of images of scientists in each year of books:

$2014=677,2015=800$, and $2016=199$

Recommends books for the three years we included in our study would not be considered as being very stereotypical insofar as DAST-C scores indicate. The data in Table 4 show that the means for each year $(2014,2015$, and 2016) were below 3.0, which is a relatively low DAST-C score. This is a desirable result given science educators' attention to reducing students' stereotypical perceptions of scientists over the past 25 years. One conclusion that can be drawn from this is that the books in the NSTA lists were clearly overcoming the resistance to change noted in 2002 by Finson. By digging more deeply into the individual elements of the DAST-C, however, there are some things that seem to persist at relatively high levels. These include the number of images showing 


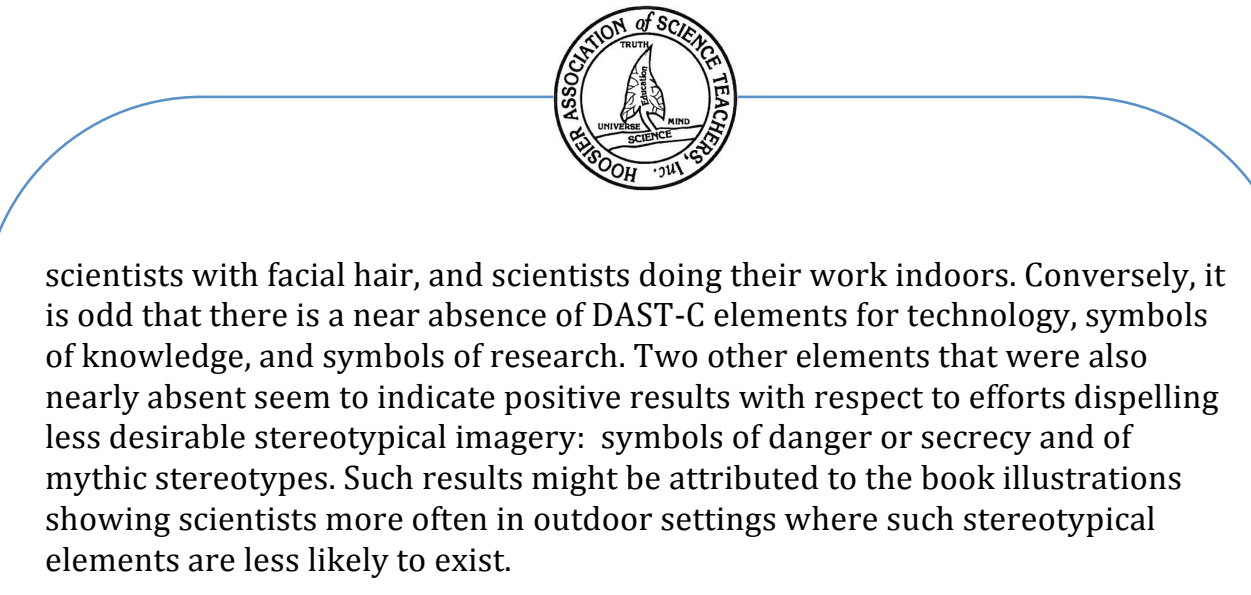

Overall, the results discussed above seem to be positive news. Even so, there are three points that arose in analysis of the data that bear further consideration. Those are stereotypical elements of gender, race/ethnicity, and age. All three were clearly present in the books across all three years.

\section{Gender Concerns}

As early as 1990, Bazier and Simonis noted science textbooks clearly delivered the message that science was a male endeavor and the accomplishments of females were scant, missing, trivialized, or even criticized. They also found that when females were included in the books, the presentation showed them in passive roles such as being helpers or doing clerical tasks. In addition, the books typically omitted topics that would be of interest to females (e.g. testing of hair coloring products in a laboratory setting or mother animals nurturing their young).

Our analysis of the portrayal of scientists in the NSTA Recommends books show images remain predominantly male. In 2014 , over $64 \%$ of the images were of males. This increased in 2015 and in 2016, with both years exceeding $70 \%$. This is clearly not the direction educational researchers desire conceptual imaging of scientists to be going with respect to gender representation. This has significant implications for students. In 1989, Fort and Varney noted that even though $60 \%$ of the 1,600 students in their study were female, only about $10 \%$ of the drawings they obtained were of female scientists. Conceptually, this translates into many female students not seeing themselves in the roles of scientists. Notably, it is historically prevalent that females are very underrepresented in science fields and in science publications, and numerous efforts have been made to increase the role of females in science, beginning at the elementary school level and continuing post-college. These efforts have included providing role models and images showing female scientists. Such interventions have been 
shown to positively impact students' perceptions of scientists (Finson, Beaver, \& Cramond, 1995). In 2012, Farland-Smith examined critical aspects for science identity construction in young girls dependent upon personal and social interactions between the girls and scientists. Bohrmann and Akerson (2001) similarly found that interventions including giving specific praise, utilizing guest speakers, viewing videos of scientists from minority populations, and ensuring equal participation in science activities by students of both genders resulted in students having fewer stereotypical images of scientists.

There are also other things that significantly impact students' perceptions of scientists. Three of them have been identified by researchers to be textbooks, trade books, and media such as movies and television. (Farland-Smith et al., 2014; Steinke et al., 2007). Researchers' recommendations have been that picture trade books should include images of both males and females and the images should be historically accurate and as non-stereotypical as possible (Farland, 2006a; Farland, 2006b). In their 2014 study, Farland-Smith et al. investigated the role of books (among other influences) in students' formation of perceptions of scientists. They found that females in their study sample exhibited a higher level of sophistication in their perceptions of scientists - i.e. more expansive -- as compared to the perceptions of male students. They also found that media appear to be greater influences on males than females, whereas school is a greater influence on females than on males. This is an important point because trade and picture books in a school's curriculum that are devoid of female representations may contribute to their perceptions of scientists and their science identities.

\section{Race and Ethnicity Concerns}

As we looked at the data from the NSTA Recommends books, another major concern arose regarding the portrayal of scientists from racially and ethnically minority populations. Caucasian scientists by far outnumbered any other races/ethnicities in each of the years of books. Caucasian scientists comprised $95.4 \%$ of the images in the 2014 books, $97.17 \%$ in 2015 , and $89.19 \%$ in 2016. Historically, science (particularly in the U.S.) has largely been perceived as an enterprise for non-minorities. A study by National Center for Science and Engineering Statistics at the National Science Foundation (Milan and Hoffer, 2012) found that in 2008, 78\% of US citizens and permanent residents who received their doctorate degree in science, engineering, and health fields reported their race/ethnicity to be White. In his 1983 study, Chambers found 


\begin{abstract}
Caucasian students typically drew images of scientists who were also Caucasian, but minority students rarely drew images of minority scientists, and instead typically drew images of Caucasian scientists. In 1995, Sumrall found similar results. Cavanaugh and Cavanaugh (2005) concluded that for many children, what is presented to them is often interpreted in ways that help them define what they perceive to be culturally acceptable thinking and behavior, and this has some effect on children's idea of the word "scientist. When comparing U.S. and Chinese student drawings, Farland-Smith (2009) found that culture continued to play a significant role in students' conceptions of scientists. Consequently, students from underrepresented populations have difficulty seeing themselves as scientists. This underscores a critical need for educators to provide role models and images that support the perception that scientists can be from all races/ethnicities. Clearly, if minority students cannot self-identify and connect with the illustrations of scientists in picture books, then there is a decreasing likelihood those students will develop positive science identities, take further science, or eventually seek science careers.
\end{abstract}

\title{
Age Concerns
}

Interestingly, the ages of scientists portrayed in the NSTA Recommends books seem to be getting younger each year. In $2014,42.53 \%$ of the images showed middle-aged or older scientists, declining to $32.08 \%$ in 2015 and dropping to $12.16 \%$ in 2016. The stereotypical and historic image of scientist has been of men of middle age and older. To many young learners, such perceptual images deliver the message that science is not for younger people. As with gender and race/ethnicity issues, serious interventions have been undertaken to dispel this perception. The trend in the NSTA Recommends books from 2014 through 2016 show a very positive move in presenting scientists as increasingly younger people with whom students can more easily relate and - as a consequence - see themselves emulating in the future. Yet there is also a note of caution that should be drawn from this, and it is that the wisdom and experience of older scientists may not be seen as valuable or important. Clearly, a more appropriate balance of age representations in science books would be warranted.

\section{Implications for Teachers}

It is important teachers plan student-centered activities that give them opportunities to explore their world and encourage them to think of themselves as scientists. Teachers can plan and deliver instruction that enables students to move closer to that goal and still successfully address key components of state 


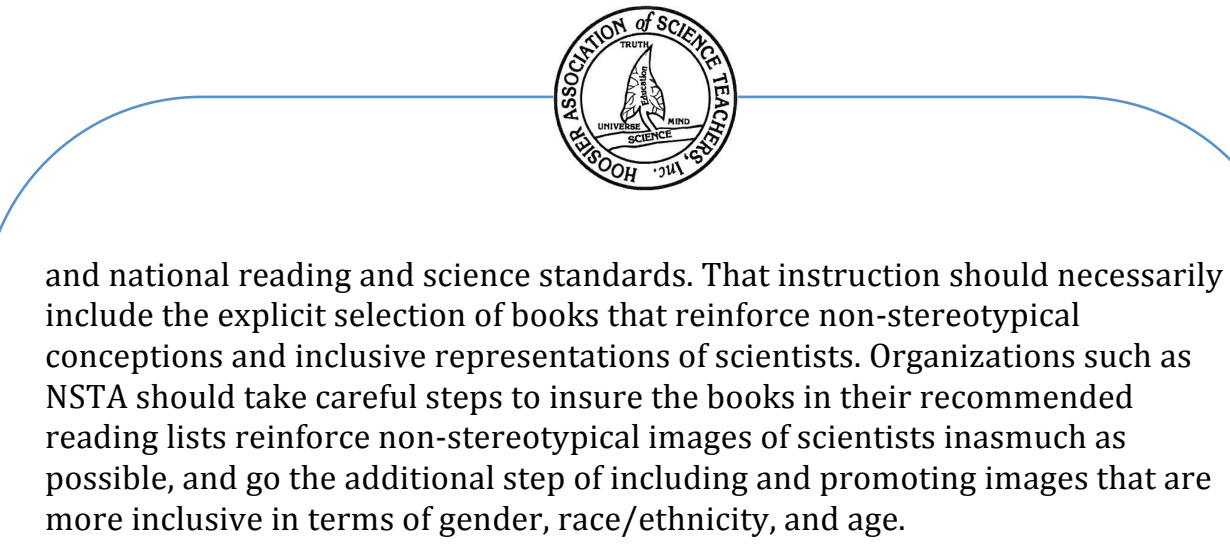

It is likely many teachers rely on the guidance from respected book listings such as NSTA Recommends to select the trade and picture books they use in their classrooms. By their inclusion in these lists, books are implicitly viewed by teachers as being well vetted and of high quality with regard to their use in classrooms. As we found in this study, teachers may need to approach the use of such lists with more caution. It may be warranted teachers give additional attention to the way scientists are portrayed in the books rather than automatically accepting the books as appropriate due to their inclusion on a list. The results of our study indicate science educators, teachers, professional organizations and publishers all need to be clearly aware of what constitutes stereotypical representations of scientists and work to minimize such representations in the materials they use with students. Employing such diligence will positively contribute to the ongoing efforts from the past 25 years to present science as a more inclusive discipline that is open to females and minorities. Such action will move science education forward, help insure national standards are met, and bring strengthening diversity to the field. 


\section{APPENDIX A}

RATER: STUDENT ID/NAME: ASSESSMENT: $\quad 1 \quad 2 \quad 3$

\section{DRAW-A-SCIENTIST CHECKLIST}

1. Lab Coat

2. Eyeglasses

3. Facial Growth of Hair (beards, mustaches, abnormally long sideburns)

4. Symbols of Research (scientific instruments, lab equipment of any kind)

a. Size of Scientific Instruments/Equipment in Relation to Scientist:

1....Small

2. ....Normal

3. ..Large

b. Types of Scientific Instruments/Equipment:

5. Symbols of Knowledge (principally books, filing cabinets,

clipboards, pens in pockets, etc.)

6. Technology (the "products" of science)

a. Types of Technology (tv, telephone, missiles, computers, etc.):

7. Relevant Captions (formulae, taxonomic classification, the "eureka!" syndrome)

\section{ALTERNATIVE IMAGES:}

8. Male Gender

9. Caucasian

10. Indications of Danger

11. Presence of Light Bulbs

12. Mythic Stereotypes (Frankenstein creatures, Jekyll/Hyde figures, "Mad/Crazed") ...

13. Indications of Secrecy (signs or warnings of "Private", "Keep Out",

"Do Not Enter”, "Go Away”, “Top Secret”, etc.)

14. Scientist Doing Work Indoors

15. Middle Aged or Elderly Scientist

NOTE: Several indicators of the same type in a single drawing count as ONE indicator (e.g. Two scientists each with eyeglasses counts as one, not two)

16. Open Comments (dress items, neckties/necklaces, hair style/grooming, smile or frown, stoic expression, bubbling liquids, smoke/steam, type of scientist - chemist, physicist, etc., -- etc.):

UPPER / LOWER SCORE: / TOTAL SCORE:

(C) 1990 Kevin D. Finson, John B. Beaver, \& Bonnie L. Cramond 


\section{References}

American Association for the Advancement of Science. (1993). Benchmarks for science literacy: Project 2061. New York: Oxford University Press.

Andrews, J., Scharff, L., \& Moses, L. (2002). The influence of illustrations in children's storybooks. Reading Psychology, 23(4), 3223-2339.

Archer, L., Dewitt, J, Osborne, J., Dillon, J., Willis, B., \& Wong, B. (2009). Construction of science through the lens of identity. Science Education, 94(4), 617-639. DOI 10.1002/sce.20399

Association for Library Services to Children (2016). Caldecott Medal terms and criteria. Retrieved April 9 $9^{\text {th }}, 2016$ from:

http://www.ala.org/alsc/awardsgrants/bookmedia/caldecottmedal/caldecottte rms/caldecottterms

Bazler, J. \& Simonis, D. (1990). Are women out of the picture? Sex discrimination in science texts.The Science Teacher, 57 (9), 24-26. Retrieved from Women's Studies International database.

Bohrmann, M.L., \& Akerson, V.L. (2001). A teacher's reflections on her actions to improve her female students' self-efficacy toward science. Journal of Elementary Science Education, 13(2), 41-55.

Brickhouse, N.W., \& Potter, J.T. (2001). Young women's science identity information in an urban context. Journal of Research in Science Teaching, 38, 965-980.

Carlone, H.B. (1994). The cultural production of science in reform-based physics: Girls' access, participation, and resistance. Journal of Research in Science Teaching, 37, 871-889.

Chambers, D. W. (1983). Stereotypic images of the scientist: The Draw-a-Scientist

Test. Science Education, 67(2), 255-265.

Durkin, D. (1974). Teaching them to read. (2 ${ }^{\text {nd }}$ ed.) Boston, MA: Allyn and Bacon.

Fang, Z. (1996). Illustrations, text, and the child reader: What are pictures in children's storybooks for? Reading Horizons, 37(2), 130-142.

Farland. D. (2006a). Effect of historical, non fiction, trade Books on elementary students' perceptions of scientists. Journal of Elementary Science Education, 18(2), 33-50.

Farland, D. (2006b). Trade books and the human endeavor of science. Science and Children, 44, 35-37.

Farland-Smith, D. (2009). How does culture shape students' perceptions of scientists? Cross-National comparative study of American and Chinese elementary students. Journal of Elementary Science education, 21(4), 23-42. 
Farland-Smith, D. (2012). Personal and social interactions between young girls and scientists: Examining critical aspects for identity construction. Journal of Science Teacher Education, 23: 1-18. DOI 10.1007/s10972-011-9259-71

Farland-Smith, D., Finson, K.D., Boone, W.J., \& Yale, M. (2014). An investigation of media influences on elementary students' representations of scientists. Journal of Science Teacher Education, 25(3), 355-366; DOI 10.1007/s10972-012-9322-z.

Finson, K.D. (2002). Drawing a scientist: What we do and do not know after fifty years of drawings. School Science and Mathematics, 102(7), 335-345.

Finson, K.D. (2003). Applicability of the DAST-C to the images of scientists drawn by students of different racial groups. Journal of Elementary Science Education, 15(1), 15-26.

Fort, D.C. \& Varney, H.L. (1989). How students see scientists: Mostly male, mostly white, and mostly benevolent. Science and Children, 26(8), 8-13.

Fung, Y. (2002). A comparative study of primary and secondary school students' images of scientists. Research in Science \& Technological Education, 20(2), 199213.

Glenberg, A.M. \& Langston, W.E. (1992). Comprehension of illustrated text: Pictures help to build mental models. Journal of Memory and Language, 31, 129-151.

Hefflin, B. R. \& Barksdale-Ladd, M. A. (2001). African American children's literature that helps students find themselves: Selection guidelines for grades K-3. The Reading Teacher, 54(8), 810-819.

Kazempour, M. (2014). I can't teach science! A case study of an elementary pre-service teacher's intersection of science experiences, beliefs, attitude and self-efficacy. International Journal of Environmental \& Science Education. 9, 77-96.

Koch, J. (1992). Elementary science education: Looking through the lens of gender. Initiatives, 55(3), 67-71.

Mead, M. \& Metraux, R. (1957). Image of the scientist among high school students: A pilot study. Science, 126, 384-390.

Milan, L., and Hoffer, T. (2012). Racial and ethnic diversity among U.S.-educated science, engineering, and health doctorate recipients: Methods of reporting diversity, NSF 12-304. Arlington, VA: National Science Foundation, National Center for Science and Engineering Statistics. Available at: http://www.nsf.gov/statistics/infbrief/nsf12304/

Myer, W. D. (March 15, 2014). Where are the people of color in children's books? The New York Times.

NGSS Lead States. (2013). Next generation science standards: For states, by states. Washington, D.C.: The National Academies Press. 
National Research Council (NRC). (2012). A Framework for K-12 science education. Practices, Crosscutting Concepts, and core ideas. Washington, D.C.: National Academy Press.

National Research Council (NRC). (1996). National science education standards. Washington, D.C.: National Academy Press.

O’Brien, V., Kopala, M., \& Matrinez-Pons, M. (1999). Mathematics self-efficacy, ethnic identity, gender, and career interests related to mathematics and science. Journal of Educational Research, 92, 231-235.

Ottaviani, J \& Wicks, M. (2013). Primates: The fearless science ofJane Goodall, Dian Fossey, and Biruté Galdikas. New York, NY: Palgrave USA.

Pappas, C.C. (2006). The information books genre: Its role in integrated science literacy research and practice. Reading Research Quarterly, 41, 226-250.

Potter, E. \& Rosser, S. (1992). Factors in life science textbooks that may deter girls' interests in science. Journal of Research in Science Teaching, 29 (7), 669-686.

Segun, M. (1988). The importance of illustrations in children's books, in Segun (Ed.) Illustrating for Children. Ibadan: CLAN, pp 25-27

Shope, R.E. III (2006). The Ed3U science model: Teaching science for conceptual change. Retrieved from http://theaste.org/publications/proceedings/ 2006proceedings/shope.html.

Steinke, J., Lapinski, M.K., Crocker, N., Zietsman-Thomas, A., Williams, Y., Evergreen, S.H., \& Kuchibhotla, S. (2007). Assessing media influences on middle school aged children's perceptions of women in science using the Draw-A-Scientist Test (DAST). Science Communication, 29; 35. DOI: 10.1177/1075547007306508. Sumrall, W.J. (1995). Reasons for the perceived images of scientists by race and gender of students in grades 1-7. School Science and Mathematics, 95(2), 83-90. Tapscott, D. (2009). Grown up digital. How the net generation is changing your world. New York: McGraw Hill.

Verhallen, M.J.A.J. \& Bus, A.G. (2011). Young second language learners' visual attention to illustrations in storybooks. Journal of Early Childhood Literacy, 11(4), 480-500. Wolfenbarger, C.D. \& Sipe, L.R. (2007). A unique visual and literary art form: Recent research on picturebooks. Language Arts, 84(3), 273-280.

Xiung, Y. (2009). Levels of meaning and children: An exploratory study of picture books' illustrations. Library \& Information Science Research, 31, 240-246.

\section{APA reference for this article:}

Finson, K. D., Farland-Smith, D., \& Arquette, C. (2018). How scientists are portrayed in NSTA Recommends books. The Hoosier Science Teacher 40(2), 4763. Doi: $10.14434 /$ thst.v41i123186 